\title{
The economic impact of NGOs on the well-being of extended households in Soweto
}

Mojalefa Rooderick, Phillip Blaauw and Rinie Schenck

\begin{abstract}
Extended households, usually in the form of an elder or grandparent, have always provided a safety net for orphaned children. However, the high rates of HIV (AIDS) infection, unemployment and poverty have weakened their capacity to fulfil this vital role. The majority of extended households live in poverty and, therefore, lack sufficient resources to care for these children. In addition to receiving government social grants, some extended households are also receiving financial and non-financial assistance from local non-governmental organisations (NGOs). These local NGOs provide basic needs such as food, clothes and medical care to orphans living in extended family units. Little has been done to quantify their economic impact. This paper, therefore, investigates the economic impact of NGOs in improving the well-being of vulnerable orphaned children living in extended households in Soweto. Using Foster, Greer and Thorbecke's (FGT) poverty indices, we found that the help of NGOs was statistically significant in reducing of poverty in such dwellings. The results of FGT are supported by those of the logit econometric model.
\end{abstract}

\section{Introduction}

Child poverty is remarkable high in South Africa and more dominant in rural areas (Dieden and Gustafson, 2003). Burger, Van der Berg, Gustafsson, Adams, Coetzee, Moses, Spaull, Swanepoel, Viljoen and Zoch (2015) in a recent report to the South African Human Rights Commission and the United Nations Children's Fund (UNICEF) asserted that $41 \%$ of children (61/2 million) are classified as chronically poor. A further $32 \%$ (5 million) live in households that moved in and out of poverty between 2008 and 2012. Most chronically poor children are also structurally poor. They live in households with too few assets and productive potential to break out of poverty (Burger et al., 2015). The high level of child poverty in South Africa and sub-Saharan Africa is dominantly caused by the increasing number of orphaned and vulnerable children (OVCs) (UNICEF, 2008; 2003).

In the context of this paper we use the World Bank's (2005:1) definition of OVCs:

"The concept generally refers to orphans and other groups of children who are more exposed to risks than their peers. In an operational context we can say that they are the children who are most likely to fall through the cracks of regular programs, or, using 
social protection terminology: OVC are groups of children that experience negative outcomes, such as the loss of their education, morbidity, and malnutrition, at higher rates than do their peers."

The global number of OVCs was estimated at approximately 153 million in 2012. Approximately 53.1 of these were residing in sub-Saharan Africa at the time. This number represents $12 \%$ of all the children in this region (Tanga, 2013; UNICEF 2012). In South Africa, there were approximately 2.2 million OVCs in 2007, and this numbers was expected to increase to 5.2 million in 2015 (Clover, Gardner and Operario, 2009). It is, furthermore, estimated that 2.3 million children will be orphaned due to AIDS in South Africa by 2020 (Korevaar, 2009).

The majority of OVCs live in extended households usually with an elder, mostly in the form of a grandparent, who assumes the responsibility of being a caregiver (Casale and Whiteside, 2006). Foster and Williamson (2000:4) define the extended family as follows: "Extended families involve a large network of connections among people extending through varying degrees of relationship including multiple generations, over a wide geographic area and involving reciprocal obligations".

Approximately two thirds of all orphaned children in South Africa are living in extended households (Tanga, 2013; Foster, 2000). Most of the extended households with orphan care responsibilities are forced to subsist under poor socio-economic conditions and depend on government social grants for their material survival. Consequently, the majority of extended households live in poverty and, therefore, lack sufficient resources to care for these children. The development of any child may be influenced negatively in the wake of inferior access to services, adverse environmental circumstances, insufficient provisions, social volatility and dispirited and overworked caregivers (Tanga, 2013; Blaauw, Viljoen and Schenck, 2011; Korevaar, 2009; Richter, Foster and Sherr, 2006; Bachmann and Booysen, 2004).

In addition to receiving government social grants, some extended households are also receiving financial and non-financial assistance from local non-governmental organisations (NGOs) (Tanga, 2013). These local NGOs play an important role in strengthening these households by providing in addition to psycho-social support, basic needs such as food, clothes and medical care to orphans living in extended family units. However, despite the significant role of local NGOs, little has been done to quantify their economic impact. It is against this background that this paper strives to bridge this gap by investigating the economic impact of NGOs in improving the well-being of vulnerable orphaned children living in the extended households of Soweto. In this study well being is using the Capability Approach's description. According to Neff (2007) the CA argues that well-being is promoted with the expansion of capabilities and freedoms. 


\section{Literature review}

In the literature, there are three different methods of caring for OVCs.

\section{The role of extended households in caring for OVCs}

The role of extended households in providing a refuge for OVCs and reducing childhood poverty, has received extensive attention in the literature. Extended households, as safety net for OVCs, are mostly preferred as an efficient model of care compared to institutional care or orphanages (Tanga, 2013; Korevaar, 2009; Beard, 2005; Booysen, 2005; Foster, 2002, 2000; Foster and Williamson, 2000). This is because children are raised within the family and form part of a large society. Extended family units ensure that children are taken care of because household members help each other socially, economically and emotionally (Foster, 2002).

Extended households have, however, in many cases, been overburdened by the high prevalence of HIV and AIDS, unemployment and poverty, compromising their care-taking and provision roles (Tanga, 2013; Korevaar, 2009; Swift and Maher, 2008; Foster and Williamson, 2000). Caregivers are often infected with HIV and AIDS themselves, forcing older orphans to take on the role of caregivers to young orphans. In some extended households, orphan care is given by older orphans, making the extended household's members vulnerable in terms of securing their basic needs (Ntozi, Ahimbisibwe, Ayiga, and Okurut, 1999). These households are known as 'child-headed households' in the literature. There is also evidence that orphan care is being given by grandparents who have even less capability of taking care of orphans. Grandparents taking care of orphans face difficulties in terms of providing food, school and medicine (Nyambedha, Wandibba, and Hansen, 2003). As a result, most orphans leave school to find work in order to supplement their family income. Therefore, although the extended household approach is preferred to institutional care, the high prevalence of poverty and HIV and AIDS has weakened the role of the extended households being the primary recourse to having orphans' basic needs satisfied (Tanga, 2013).

\section{Government intervention in caring for vulnerable orphaned children}

Governments have responded to the high level of orphaned children through cash transfers). In South Africa, the government introduced foster care grants and the child support grant in an attempt to improve the well-being of OVCs living in extended households. The foster care grant is a social transfer made by the government to these caregivers (Tanga, 2013; Patel, 2012).

The effectiveness of social grants in improving the well-being of orphaned children has received wide empirical investigation. Case, Hosegood and Lund (2005) evaluated the impact of social grants on school enrolment in KwaZulu-Natal. They found that children who received social grants were more likely to enrol in school than those who did not. Booysen (2005) found that social grants reduce the severity of poverty in extended households affected by HIV and AIDS in South Africa. 
The social grants were found to push household per capita income closer to the poverty line. The decrease in the levels of poverty for the period 1993 and 2004 is mostly linked to the expansion of cash transfers, irrespective of which poverty line is used. Therefore, social grants reduce the depth of poverty and the poverty gap, especially for the poorest of the poor (Patel, 2012; Barrientos and De Jong, 2006).

\section{NGOs' interventions in caring for orphans}

Thirdly, community-based groups, such as NGOs, evolved from the need to help extended households caring for orphans in terms of food, medical care and school expenses. These NGOs evolved because: HIV and AIDS had weakened the role of the extended households as a safety net for caring for orphaned children (Tanga, 2013; Korevaar, 2009; Swift and Maher, 2008) and, because of government assistance, in the form of foster care grants, not always being capable of boosting extended households' income levels above the threshold poverty line (Booysen 2005; Oni, Obi, Okne, Thabede and Jordann, 2002). There is less literature, if any, investigating the economic role of local NGOs providing help to extended households caring for orphans. This study strives to close this knowledge gap by investigating the economic impact of NGOs.

\section{Methodology}

\section{Population and research site}

The targeted population was households receiving NGO assistance as a result of caring for orphaned children in Soweto under the age of 18 years. Soweto was selected because it has more NGOs than any other urban township in the city of Johannesburg. The Department of Social Development's (DSD) database shows that there were 140 registered NGOs in Soweto in 2013. Soweto is also one of the poorest areas in Johannesburg (Mears 2012; Patel, 2012).

The level of poverty is still remarkably high in Soweto. Mears (2012) estimated that the mean household income per month in Soweto was R6 500.00 in 2008. Using the minimum living levels (MLLs) of R1 023.00, R1 261.00, R1 635.00, R1 998.00 and R2 786.00 for the first, second, third, fourth and fifth quintiles, respectively, Mears (2012) found that approximately $40 \%$ of the population in Soweto lived on income below their MLLs at the time. Since children are over-represented in poor households, it is likely that childhood poverty is also high in Soweto. Given the number of NGOs and the level of poverty, Soweto is an appropriate area to investigate the impact of NGOs on improving the well-being of orphaned and vulnerable children living in extended households.

\section{Sampling \\ Sampling of NGOs}

Not all the 140 NGOs in Soweto meet the criteria to be included in this study. The NGOs that provide help to the extended households living with at least one or more orphaned child(ren) meet the sample selection criteria. The NGOs that meet the sample selection criteria were identified with the help of the Gauteng Department of Social Development (GDSD). There are 39 NGOs in the City of Johannesburg that meet the criteria to be part of 
this study. From the 39 NGOs identified, 13 are in Soweto, all of which were included in this study.

\section{Sampling of households across the NGOs}

When defining a household, this study follows the definition of Mutangdura and Webb (1998:49), who define a household "as an economic unit consisting of a group of people living in the same dwelling and who dine together for at least 3 to 12 months in a year". Therefore, members of the households who reside in a different place were not included as household members. Furthermore, the members of the household who reside in the same yard of the original household, but who do not dine with the household members, were also not included as household members.

The households within each NGO were pulled together and a systematic random sampling method was used to select the representative sample of households. This was done by asking each NGO to give the number of households they help. All the households from each NGO were put together in a list. Using the list, the sample was then selected by using an interval of 2. The interval of 2 was used because a sample of 50\% from the population was targeted. After aggregating the households across all the NGOs, the total number of households was 406. This was the research population from which the sample was drawn. Therefore, using a systematic random sampling method, 203 households were selected to be sampled. This constituted 50\% of the research population. From 203 households, only 119 were successfully interviewed. This is because some households were not available during the interviews and others refused to participate in the study.

After screening all the survey instruments, 51 households out of 119 were dropped. This is because orphans who are living in these households were older than 18 years of age. Therefore, the total number of households used in this study is 68 . This constitutes $32 \%$ of the targeted sample and $17 \%$ of the research population. Although this is a small sample, statistically, a researcher needs "at least 30 observations before you can reasonably expect an analysis based upon the normal distribution (i.e. $\mathrm{z}$ test) to be valid. That is it represents a threshold above which the sample size is no longer considered 'small”' (Rout, 2015:1).

\section{Data collection}

The data were collected through interviewing the sampled households. A structured survey questionnaire was designed and ethical clearance was obtained from the Faculty of Economic and Financial Sciences at the University of Johannesburg. In order to acquire the correct information, the heads of the households were interviewed. In cases where the head of a household was not available, the oldest available member of the household was interviewed. Information about the household expenditure and income per month in current prices, the household size, as well as the age, gender and the level of education of the head of the household was collected. Since the aim of the study is to assess the economic impact of the NGOs, the questionnaire contained questions about the help provided by the NGOs to households. This included: the value of food parcels, in current prices, provided by NGOs; 
the money given to households; school fees paid by NGOs; and any other help such households received from these NGOs.

The surveys were conducted from July 2014 until August 2014. Screening of the questionnaires and capturing of a data took place during September 2014. The surveys were conducted with the help of one third-year and one honours student from the University of Johannesburg who were fluent in isiZulu. This was an advantage, since the majority of people in Soweto are isiZulu-speaking or can speak isiZulu (Mears, 2012). The students were given training and the objective of the study was made clear to them before the fieldwork commenced.

\section{Research approaches}

The research approaches used in this study require a specification and measurement of a poverty line. In South Africa, like many other developing countries, there is no official poverty line, but different departmental definitions (Gumede, 2008). For the purpose of this paper, the poverty line of R593.00 per capita per month was used. This poverty line is used by the Department of Social Development. Therefore, in this paper, R593.00 per capita per month is the income or expenditure needed to achieve the minimum level of well-being required not to be deemed poor.

The expenditure, as opposed to income, was used as a measure of poverty in this study. This is because using income as a measure of poverty is criticised in the literature because people underestimate their income in survey data.

\section{First approach: Foster, Greer and Thorbecke's poverty indices}

In the first approach, the per capita expenditure of the households, excluding and including the help from NGOs, was determined. Using this approach, the help from NGOs was treated as an exogenous household expenditure. The Foster, Greer and Thorbecke poverty (FGT) indices (1984) were then used in order to assess the impact of NGOs' help on poverty incidence and closing the poverty gap. The FGT poverty indices were developed in 1984. See Foster et al. (1984) for a detailed description thereof. The FGT poverty indices were used because this is a widely used approach in the literature to assess the impact of exogenous income/expenditure on poverty incidence and the poverty gap (Booysen, 2005; Bhorat, 2003; Samson, 2002; Leibbrandt and Woolard, 2001). In this study, we follow the same approach.

Unlike some of the other studies, we test for the significance of NGOs' help using the Kruskal-Wallis (1952) non-parametric test. See Kruskal and Wallis (1952) for a formal mathematical explanation of the Kruskal-Wallis (1952) non-parametric test.

\section{Second approach: The logit econometric model}

In the second approach, we used the logit econometric model as a control method to account for other variables that affect the probability of an orphaned child to be poor. Since the well-being of an orphaned child is measured at the household level, these 
variables are the head of household characteristics that affect the probability of an orphaned child to be poor.

The logit model was used for two reasons: firstly, because the independent variables used in this study are a mix of continuous and categorical variables; and, secondly, the dependent variable is a dichotomous/binary variable, with a value of one and zero. The choice of the variables follows those used by Bogale, Hagedorn and Korf (2005). Bhatta and Sharma (2006) also used the same variables when determining poverty in Nepal. Since the study is about quantifying the help of NGOs, the help of NGOs was added as a variable of interest. Although variables used in this study are those widely used in the literature, the model specification was tested using the link test. The results of the link test confirm that the model was correctly specified.

The following logit model was, therefore, estimated:

$$
\text { Pov }_{i}=B_{0}+B_{1} H F N_{i}+B_{2} M R T_{i}+B_{3} G E N D_{i}+B_{4} A G E_{i}+B_{5} E D U_{i}+\mu_{i}
$$

Where Pov is a poverty variable taking a value of one if a household is poor and zero otherwise. $H F N$ is the help from the NGOs, $M R T$ is the marital status of the household head, GEND is the gender of the household head, $A G E$ is the age of the household head, and $E D U$ is the level of education of the head of the household. The $B B s$ are parameters to be estimated.

Equation 1 was estimated using the maximum likelihood (ML) technique.

\section{Analysis of the results Demographic profile}

A total of 68 households were surveyed. From all households surveyed, 63\% are headed by females and the remaining $37 \%$ by males. These results are similar to those found by Dieden and Gustafsson (2003), who found that in 2002 approximately two-fifths of children in South Africa lived in female-headed households. These households are more vulnerable to poverty than households led by males.

The average number of people in a household is five. This is more than the national average household size of 3.9 and the Gauteng provincial average household size of 3.3 (Statistics South Africa (StatsSA), 2011, 2007). These results are expected since households in this study have orphaned children living with them. These households are referred to as 'extended households/families' in the literature. Dieden and Gustafsson (2003) suggest that there is a positive relationship between poverty and household size. these households is, therefore, expected to be higher than the average South African household. The age distribution for the household heads is as follows: $4 \%$ of households are headed by persons who are younger than 18 years old; $13 \%$ by persons between the age of 18 
and 30; $53 \%$ of households are led by custodians between the age of 31 and 50; and the remaining $30 \%$ are governed by persons above 50 years of age.

These results support Nyambedha et al. (2003), which asserts that elder caregivers have less capability to care for orphaned children. Consequently, the majority of orphaned children are living with young adults who are in the age group of 31 to 50.

With regard to the level of education, 30\% of household heads have obtained education ranging from grade o to $9 ; 53 \%$ of these headers have obtained education ranging from grade 10 to 12 ; and the remaining $17 \%$ have a post-secondary education.

Approximately half of household heads (45\%) are single and have never been married, $4 \%$ of household heads are divorced and $22 \%$ are married. The remaining $10 \%$ of household heads are living with their partner and $18 \%$ are widowed. Therefore, the majority of orphaned children are living with young, single females.

\section{Foster, Greer and Thorbecke's poverty indices}

This section presents the results of NGOs' help in decreasing poverty incidence and closing the poverty gap.

\section{The impact of NGOs' help on poverty incidence (level of poverty)}

In the first method, the impact of NGOs' help in minimising poverty incidence was assessed by calculating the poverty incidence with regard to situations where expenditure is exclusive of NGOs' aid, and contexts where it includes NGOs' help. The comparison makes it easy to track the number/percentage of households who are lifted out of poverty after they have received these hand-outs. Table 1 reports the results.

Table 1: Poverty incidence excluding and including the help from the NGOs

\begin{tabular}{|l|l|l|}
\hline & $\begin{array}{l}\text { Poverty incidence excluding } \\
\text { NGOs' help }\end{array}$ & $\begin{array}{l}\text { Poverty incidence including NGOs' } \\
\text { help }\end{array}$ \\
\hline Poor & $65 \%$ & $46 \%$ \\
\hline Non-poor & $35 \%$ & $54 \%$ \\
\hline Total & 100 & 100 \\
\hline
\end{tabular}

$(N=68$ Source: Own calculations based on survey data)

From Table 1, the poverty incidence defined for expenditure that was exclusive of NGOs' help is $65 \%$. This means that $65 \%$ of households in the sample are poor. In comparison, only $46 \%$ of households are poor when poverty incidence is defined for expenditure that is inclusive of NGOs' help. Therefore, $19 \%$ of households in the sample are elevated above the threshold poverty line when the help of NGOs is incorporated as additional household expenditure.

The Kruskal-Wallis non-parametric test was used to test for the statistical significance of the difference between the per capita expenditure of households exclusive and inclusive of NGOs' help. The difference between per capita expenditure of households excluding and including 
the help from the NGOs is statistically significant at a $1 \%$ confidence interval. This means that the help of NGOs is statistically significant in reducing the level of poverty. See Table 2.

Table 2: Kruskal-Wallis equality-of-populations rank test

\begin{tabular}{|l|l|l|l|l|}
\hline Per capita expenditure & Obs & $\begin{array}{l}\text { Rank } \\
\text { Sum }\end{array}$ & Chi-Square & Probability \\
\hline Expenditure excluding NGO help & 68 & 3717.50 & 16.756 & \multirow{2}{*}{$0.0001^{* * * *}$} \\
\cline { 1 - 3 } Expenditure including NGOs help & 68 & 5598.50 & & \\
\hline
\end{tabular}

(Own calculations based on survey data)

$* * * * *, * 1 \%, 5 \%$ and $10 \%$ level of significance, respectively

In the second method, the Kernel density function was used in order to assess the impact of NGOs' aid on poverty incidence. Figure 1 displays the Kernel density function of a log of household expenditure inclusive and exclusive of NGOs' contributions. The help from NGOs squeezes the distribution of the data upward to the left. This means that NGOs' assistance reduces the level of poverty. Secondly, the tail of the distribution increases. This means that NGOs' intervention reduces the depth of poverty.

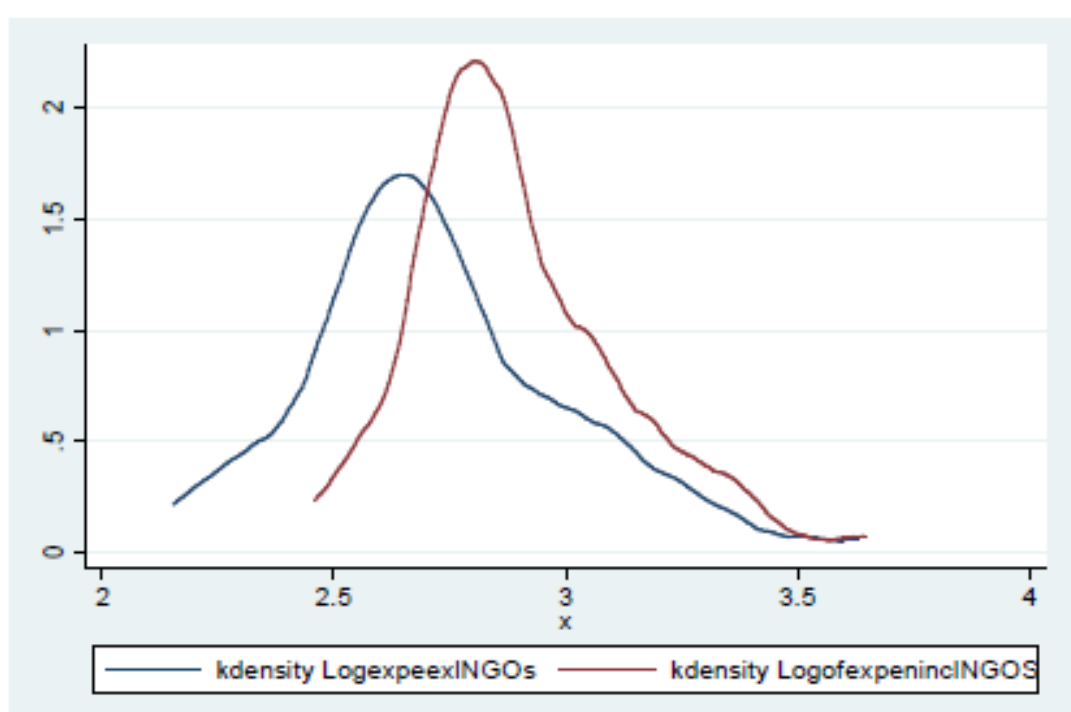

(Source: Own calculations from survey data)

Figure 1: Kernel density functions of a log of household expenditure excluding and including NGOs' help

These results have two important implications. Firstly, the help of NGOs seems to be appropriately aimed at assisting poor households. Secondly, NGOs play a very important role in reducing the level of poverty in poor households living with orphaned children.

\section{The impact of NGOs' help in closing the poverty gap (depth of poverty)}

The poverty gap measures the extent to which poor households fall below the poverty line (depth of poverty). The poverty gap is calculated by summing the gaps between the poverty line and the expenditure of each poor household. Since R593.00 per capita per 
month is the threshold poverty line used in this study, the poverty gap was calculated by summing the gaps between the threshold poverty line of R593.00 and the per capita expenditure of each poor household in the sample. The addition of these gaps provides a minimum cost of eliminating poverty. The minimum cost of eliminating poverty is called the 'aggregate poverty gap'.

The impact of NGOs' help on the poverty gap was assessed by comparing the aggregate poverty gap and the per capita poverty gap for expenditure both inclusively and exclusively of NGOs' help. The per capita poverty gap is an average amount that each poor household needs in order to be out of poverty.

Table 3 reports the aggregate poverty gap for expenditure defined as exclusive and inclusive of NGOs' help for the sample of 68 households used in this study.

Table 3: Poverty gap including and excluding NGOs' help

\begin{tabular}{|l|l|l|}
\hline Poverty gap & Monetary value & Per capita poverty gap \\
\hline Excluding NGOs' help & R6 200.00 & R140.00 \\
\hline Including NGOs' help & R4 000.00 & R129.00 \\
\hline
\end{tabular}

(Source: Own calculation based on survey data)

From Table 3, the aggregate poverty gap defined for expenditure exclusive of NGOs' help is R6 200.00. This means that in the absence of NGOs' help, poor households in the sample will need R6 200.00 to be out of poverty. The number of poor households, when the help of NGOs is excluded from households' expenditure, is 44 . Therefore, the average poverty gap per household is R140 (6 200/44). This means that each poor household needs, on average, an additional R140 to have a per capita expenditure of R593.00. In comparison, the aggregate poverty gap for expenditure defined inclusive of NGOs' help is R4 0oo.oo. Therefore, the aggregate poverty gap decreases by R2 200.00 (R6 200.00 - R4 000.00) when the help of NGOs is incorporated as household expenditure. The number of poor house-holds was calculated to be $31(0.46 / 68)$ when the help of NGOs was included as an additional household expenditure. Therefore, the average poverty gap per household is 129 (4 000/31). Consequently, each poor household needs, on average, R129 to be out of poverty. The aggregate poverty gap and the per capita poverty gap decreases by R2 200.00 and R11.0o respectively when NGOs' help is included as household expenditure.

The Kruskal-Wallis non-parametric test was used to test for the significance of the difference between the poverty gap inclusive and exclusive of NGOs' help. The difference between the aggregate poverty gap, including and excluding the help from the NGOs, is statistically significant at a $1 \%$ confidence interval. This means that the help of NGOs is statistically significant in reducing the depth of poverty. 
Table 4: Kruskal-Wallis equality-of-populations rank test

\begin{tabular}{|l|l|l|l|l|}
\hline Per capita expenditure & Obs & Rank sum & Chi-square & Probability \\
\hline Expenditure excluding NGO help & 68 & 5598.00 & \multirow{2}{*}{16.738} & \multirow{2}{*}{$0.0001^{\text {**** }}$} \\
\cline { 1 - 4 } Expenditure including NGOs help & 68 & 3718.00 & & \\
\hline
\end{tabular}

(Own calculations based on survey data)

水水, 水, , represents the traditional $1 \%, 5 \%$ and $10 \%$ level of significance, respectively

\section{Logit econometric model}

Four control variables, which, according to the theory and the literature, are believed to influence the level of poverty, were used (Bhatta and Sharma, 2006; Bogale et al., 2005).

Table 5: Logit econometric model

\begin{tabular}{|c|c|c|c|c|c|}
\hline \multicolumn{2}{|c|}{ Logistic regression } & & $\begin{array}{l}\text { Number } \\
\text { of obs }=\end{array}$ & \multirow[t]{3}{*}{68} & \\
\hline & & $\operatorname{chi} 2(6)=$ & 35.05 & & \\
\hline & & Prob $>$ chi $2=$ & 0.0000 & & \\
\hline Log likelihood $=$ & -23.668806 & & $\begin{array}{l}\text { Pseudo } \\
\text { R2 = }\end{array}$ & 0.4254 & \\
\hline Poverty & Coef. & Std. Err. & Z & $\mathrm{P}>\mathrm{z}[95 \%$ Conf. & Interval] \\
\hline NGOhelp & -.883221 & .4311662 & 2.04 & $0.019-.1 .73663$ & .0008483 \\
\hline Gen & .7096316 & .8880547 & 0.80 & $0.424-1.030924$ & 2.450187 \\
\hline Maritast & -.2340393 & .9611262 & 0.24 & $0.808-1.649733$ & 2.117812 \\
\hline Age & -.0025483 & .0483783 & 0.05 & $0.958-.0922714$ & .097368 \\
\hline Levelofeduc $\sim \mathrm{n}$ & -.8960369 & .3666901 & 2.44 & 0.015 .1773375 & 1.614736 \\
\hline Noofhouseho s & .9112803 & .3698863 & -2.46 & $0.014-1.636244$ & -.1863164 \\
\hline cons & -7.169018 & 4.425788 & -1.62 & $0.105-15.8434$ & 1.505367 \\
\hline
\end{tabular}

*水, , 决, * represents the traditional $1 \%, 5 \%$ and $10 \%$ level of significance, respectively

From the regression results, the coefficient of NGOs' help is negative, as expected, and significant. This means that the help of NGOs reduces the probability of an orphaned child to be poor. Although the odds ratios are not reported in the table, the odds ratio of households receiving NGOs' help is 3.32, which means these households are three times more likely not to be poor compared to households not receiving any assistance. From these results, it can be concluded that NGOs play an important role in reducing the level of 
poverty in those extended households living with orphaned children. These results support the results found using the FGT poverty indices. Therefore, NGOs play a pivotal role in improving the well-being of orphaned children living in the extended households. With regard to education, the coefficient of education is negative, as expected, and significant. Orphans living in households where the head is educated are less likely to live in poverty. The odds ratio of education is 2.3, which implies that orphans living in households where the head of a household is educated are twice more likely not to be poor compared to orphans living in households where the household heads are not educated. The coefficient of marital status is negative, as expected, but insignificant. The gender coefficient is positive, as expected, but also insignificant. As expected, the coefficient of a household's size is positive and significant. The positive sign implies that the greater the household size, the greater the probability of being poor. This finding is consistent with the literature.

\section{Conclusion}

The objective of this article is to describe the economic impact of NGOs in improving the well-being of vulnerable orphaned children living in extended households in Soweto. The majority of orphaned children live with young, single females and/or grandparents. Many of the household heads have only obtained education up to grade 12, and, therefore, the level of poverty was found to be high.

The study determined that the help of NGOs reduces the level of poverty by expanding the per capita expenditure of a significant portion of the poor, launching them above the poverty line. Secondly, the help of NGOs reduces the depth of poverty by elevating the per capita expenditure of the poor close to the poverty line. It was, therefore, concluded that NGOs play a key role in reducing poverty in extended households living with orphans, thereby improving the well-being of these children.

The results of this study must be seen within the context of the broader social assistance provided by government to targeted groupings of the poor. The literature confirms that well-targeted social assistance can play an important role to address the poor's access to healthcare, education, housing, and social infrastructure (their well being). This is especially true for the poorest of the poor where low or non-existent incomes are the order of the day (Committee of Inquiry into a Comprehensive System of Social Security for South Africa, 2002). Existing social security programmes can reduce the average poverty gap. The average hides important variation and some households benefit less than others. Poor households that include pensioners are on average significantly better off than those without pensioners (Committee of Inquiry into a Comprehensive System of Social Security for South Africa, 2002).

For a combination of official social assistance and the work of NGOs to be effective, it must take cognisance of the many manifestations of poverty in South Africa. Effective policy must focus on poverty in the form of capability in the form of a lack of access to health and education; income, where there is lack of sustainable earnings or other income sources; and poverty in the form of access to resources and other assets. There is no quick 
fix, however. The effects of HIV and AIDS will be with us for many years to come. This does not mean that we should not continue the study, understand and support NGOs' efforts to help weaving the safety net stronger now. 


\section{References}

Bachmann, O.M. and Booysen, F.L.R. (2004). "Relationship between HIV/AIDS, Income and Expenditure over Time in Deprived South African Households" AIDS Care 16(7):817826.

Barrientos, A. and De Jong, J. (2006). "Reducing Poverty with Cash Transfer: A Sure Thing” Developmental Policy Review 24(5):537-552.

Beard, B.J. (2005). "Orphan Care in Malawi: Current Practices" Journal of Community Health Nursing 22(2):105-115.

Bhatta, S.D. and Sharma, S.K. (2006). "The Determinants and Consequences of Chronic and Transient Poverty in Nepal" Chronic Poverty Research Centre Working Paper 66 Manchester, UK: Chronic Poverty Research Centre (CPRC).

Bhorat, H. (2003). "Estimates for Poverty Alleviation in South Africa, with an Application to a Universal Income Grant” DPRU Working Paper No. 03/75 Development Policy Research Unit: University of Cape Town.

Blaauw, P.F., Viljoen, K. and Schenck, R. (2011). "Life is Not Pap and Vleis: Poverty in Child-headed Households in Gauteng” Social Work/Maatskaplike Werk 42(2):138-154.

Bogale, A., Hagedorn, K. and Korf, B. (2005). "Determinants of Poverty in Rural Ethiopia" Quarterly Journal of International Agriculture 44(2):101-120.

Booysen, F. (2005). "The Role of Social Grants in Mitigating the Socio Economic Impact of HIV/AIDS in Two Free State Communities" South African Journal of Economics 74(1):545-563.

Burger, R., van der Berg, S., Gustafsson, M., Adams, C., Coetzee, M., Moses, E., Spaull, N., Swanepoel, C., Viljoen, J. and Zoch, A. (2015). "Poverty Traps and Social Exclusion among Children in South Africa" Five Policy Briefs Based on a Report Initially Compiled for the SA Human Rights Commission and UNICEF Presentation at the HSRC, Cape Town, 9 November 2015 .

Casale M, and Whiteside, A. (2006). "The Impact of HIV and AIDS on Poverty, Inequality and Economic Growth" IDRC Working Papers on Globalization, Growth and Poverty No. 3 Durban: Health Economics and HIV and AIDS Research Division (HEARD), University of KwaZulu-Natal.

Case, A., Hosegood, V. and Lund, F. (2005). "The Reach and Impact of Child Support Grants: Evidence from Kwazulu-Natal” Development Southern Africa 22(4):467-482. 
Clover, L., Gardner, F. and Operario, D. (2009). "Poverty and Psychological Health among AIDS-orphaned Children in Cape To n" AIDS Care: Psychological and Socio-Medical Aspects of AIDS/HIV 21(06):237-317.

Committee of Inquiry into a Comprehensive System of Social Security for South Africa (2002). "Transforming the Present - Protecting the Future Consolidated Report of the Committee of Inquiry into a Comprehensive System of Social Security for South Africa presented to Dr ZST Skweyiya, MP, and Minister for Social Development, South Africa", http://www.cdhaarmann.com/Publications/Taylor\%2oreport.pdf (Accessed on 13/02/2016).

Dieden, S. and Gustafsson, B. (2003). "Child Poverty in South Africa: An Assessment Based on Microdata for 1995” International Journal of Social Welfare 12(4):326-338.

Foster, G. (2000). "The Capacity of the Extended Family Safety Net for Orphans in Africa" Psychology Health and Medicine 5(1):55-62.

Foster, G. (2002). "Supporting Community Efforts to Assist Orphans in Africa" New England Journal of Medicine 346(24):293-315.

Foster, G. and Williamson, J. (2000). "A Review of Current Literature of the Impact of HIV/AIDS on Children in sub-Saharan Africa” AIDS 2000 14(suppl. 3):S275-S284.

Foster, J., Greer, J. and Thorbecke, E. (1984). "A Class of Decomposable Poverty Measures" Econometrica 52:761-766.

Gumede, V. (2008). "Poverty and 'Second Economy' in Southern Africa: An Attempt to Clarify Applicable Concepts and Quantify the Extent of Relevant Challenges" DPRU Working Paper, o8/133, June 2008 Development Policy Research Unit: University of Cape Town.

Korevaar, K. (2009). A Psychosocial Description of Young Orphans Living in Childheaded Homes (Unpublished Master of Arts (MA) Mini-Dissertation) Pretoria: University of Pretoria, Department of Psychology, http://repository.up.ac.za/bitstream/handle/2263/ 27812/dissertation.pdf;sequence=1 (Accessed on 13/02/ 2016).

Kruskal, W. and Wallis, W.A. (1952). "Use of Ranks in One-criterion Analysis" Journal of the American Statistical Association 47(260):583-261.

Leibbrandt, M. and Woolard, I. (2001). "Labour Market and Household Income Inequality in South Africa: Existing Evidence and New Panel Data" Journal of International Development 13:671-689. 
Mears, R. (2012). "Demographics and Urban Characteristics of Soweto: A Comparison of 1993 and 2008". Paper Presented at the Department of Economics and Econometrics at the University of Johannesburg in 2012. Johannesburg, South Africa.

Mutangdura, G. and Webb, D. (1998). "The Socio Economic Impact of Adult Mortality and Mobility on Households in Urban Zambia" SA AIDS News 6(3):14-5.

Ntozi, J.P.M., Ahimbisibwe, F.E., Ayiga, N. and Okurut, F.N. (1999). "Orphan Care: The in Orubuloye, I.O., Caldwell, J.C. and

Ntozi, J.P.M. (Eds.). The Continuing African HIV/AIDS Epidemic Canberra: Australian

National University, National Centre for Epidemiology and Population Health, Health Transition Centre, 225-236.

Nyambedha, E.O., Wandibba, S. and Hansen, J.A. (2003). "Retirement Lost - The New Role of the Elderly as Caregivers for Orphans in Western Kenya" Journal of Cross Cultural Gerontology 18(1):35-52.

Oni, S.A., Obi, C.L., Okne, D., Thabede, D. and Jordann, D. (2002). "The Economic Impact of HIV/AIDS in Rural Households in Limpopo Province" South African Journal of Economics 70(7):551-552.

Patel, L. (2012). "Poverty, Gender and Social Protection: Child Support Grants in Soweto, South Africa” Journal of Policy Practice 11(1-2):106-120.

Richter, L., Foster, G. and Sherr, L. (2006). Where the Heart is: Meeting the Psychosocial Needs of Young Children in the Context of HIV/AIDS The Hague: Bernard Leer Foundation.

Rout, C. (2015). "What is the Rationale Behind the Magic Number 30 in Statistics?" ResearchGate, https://www.researchgate.net/post/What is the rationale behind the magic number 30 in statistics (Accessed on 13/02/ 2016).

Samson, M.J. (2002). "The Social, Economic and Fiscal Impact of Comprehensive Social Security 97 Reform for South Africa” Social Dynamics 28(2):69-121.

Statistics South Africa (StatsSA). (2007). "Community Survey" Pretoria: Government Printers.

Statistics South Africa (StatsSA). (2012). “Census 2011” Pretoria: Government Printers.

Swift, A. and Maher, S. (2008). Growing Pains: How Poverty and AIDS are Challenging Childhood London: Panos. 
Tanga, P.T. (2013). "The Impact of the Declining Extended Family Support System on the Education of Orphans in Lesotho" African Journal of AIDS Research 12(3):173-183.

United Nations Children's Fund (UNICEF). (2003). "Orphans in South Africa", http://www.unicef.org/southafrica/SAF_resources_annual2003.pd (Accessed on 13/02/16).

United Nations Children's Fund (UNICEF). (2008). "Orphan Crisis in Africa", http://www.unicef.org/southafrica/SAF resources annual2008.pd (Accessed on 13/02/16).

United Nations Children's Fund (UNICEF). (2012). "Press Centre: Orphans", http://www.unicef.org/media/media 45279.html (Accessed on 13/02/16).

World Bank. (2005). “OVC Core Definitions”, http://info.worldbank.org/etools/docs/ library/162495/howknow/definitions.htm (Accessed on 27/04/16). 